\title{
Postgraduate Education Strategy's for the Smoking Control in Cuba
}

MD Efraín Sánchez González

Assistant Professor, Faculty of Medical Science "10 de Octubre", University of Medical Science of Havana.

Corresponding Author: MD Efraín Sánchez González, Assistant Professor, PhD. Bergelino Zaldívar Pérez, Auxiliary Professor, Faculty on Nursing "Lidia Doce" University of Medical Science of Havana Faculty of Medical Science "10 de Octubre"

Received Date: October 30, 2020; Accepted Date: November 20, 2020; Published Date; January $02,2021$.

Citation: MD Efraín Sánchez González, Postgraduate Education Strategy’s for the Smoking Control in Cuba .Review Article J. Clin Case Rep and Stud. 2(1). Doi: 10.31579/2690-8808/052

Copyright: @ 2021 MD Efraín Sánchez González, This is an open-access article distributed under the terms of the Creative Commons Attribution License, which permits unrestricted use, distribution, and reproduction in any medium, provided the original author and source are credited

\begin{abstract}
Background: Smoking control is full important in Cuba. Cuban tobacco industry looks for the significant tobacco consumption growing. However, Cuban Public Health has a national program against smoking. This health institution contributes to generalist some smoking researches. By this institution is possible to call the main health professional related with the smoking control around the country. Much from these professionals haven't a sufficient academic formation in Health Economy subjects for the smoking control. This condition and previous related are showing the real necessity to make available a postgraduate strategic for the smoking economic control since the Health Economy point of view.
\end{abstract}

Objective. To design a postgraduate educational strategic for the smoking economic control in Cuba.

Materials and Methods. Theoric methods: inductive - deductive, comparative and systematization. Empiric method: bibliographic and documental research.

Results. The postgraduate educational strategic appoint to the professionals from the Public Health close related to the smoking control. It is formed by six courses, one of them is a diploma course. Inside each course a subject is supported by the previous. By this way is possible obtain a logic process in the postgraduate teaching about the smoking economic control.

Conclusions. Was designed a postgraduate educational strategic for the smoking economic control in Cuba, agree to real needs from the health professionals related with the smoking control.

Key words: postgraduate strategy; smoking; economic control

\section{Background:}

The smoking control is full important for the present Cuban society. The impact from this risk factor includes the following elements:

1) The dynamic from the social costs attributable to smoking is higher than the tobacco and cigarettes sales case's. This condition means a strong financial pressure over the health budget management. [1]

2) Cigarettes and tobaccos behavior's is agree to necessaries and ordinaries goods. As consequence the active smoker give high priority to tobacco and cigarettes consumption, similar to food. [2]

3) There is a defined structure from Cuban states which more tobacco consumes. This should be an evident economic poorness cause from these states. [3]

4) The tributary policy haven't change during 20 years. However, a recent research suggest that increasing the tobacco minor sales from $\$ 7.00$ to $\$ 11.00$ the box containing 20 tobaccos should be very good for the Public Health and the fiscal income at same time. [4]

5) The no - tributaries policies for the smoking control are few effectives.

6) Smoking carries to earlier death in labor age. This means important labor productivity lose. [5]

7) The consumption of cigarettes and tobaccos means a significant socioeconomic inequity cause. [6]

By other side recent researches from the process estimating the smoking cost are suggesting that:

a) It is necessary to modify the method to estimate the smoking economic burden by morbidity ${ }^{7}$ and the over mortality in active smokers too. [8]

b) It is necessary a whole instrument to measure the socioeconomic inequity attributable to smoking. [9]

In the opposite side the Cuban tobacco industry looks for the significant tobacco consumption growing. For example, the minor physic sales from 
the most sold tobacco in Cuba will be duplicated in 2030 respect to 2020 . [10]

Cuban Public Health has a national program against smoking. This health institution contributes to generalist some smoking researches. By this institution is possible to call the main health professional related with the smoking control around the country. [11]

Much from these professionals haven't a sufficient academic formation in Health Economy subjects for the smoking control. This condition and previous related are showing the real necessity to make available a postgraduate strategic for the smoking economic control since the Health Economy point of view. [12]

Objective: To design a postgraduate educational strategic for the smoking economic control in Cuba.

\section{Materials and Methods:}

Theoric methods: inductive - deductive, comparative and systematization. Empiric method: bibliographic and documental research.

\section{Results:}

The postgraduate educational strategic appoint to the professionals from the Public Health close related to the smoking control. It is formed by the following courses:

1-Postgraduate trainer course: The smoking economic burden by morbidity. This course was designed to teach how to measure the smoking economic impact over the health economic management. This course includes:

a) The tendency description from the smoking impact over the health economic management. [1]

b) The description from the morbidity attributable to smoking behavior's since the Health economy point of view. [13]

c) Discussion from the main ways to estimate the smoking cost over the Public Health. [14]

d) The identification of the main elements to estimate the economic burden attributable to some risk factor. [15]

e) A new formula to estimate the smoking economic burden by morbidity.[16]

f) A new algorithm to estimate the smoking economic burden by morbidity. [17]

This course is important because introduces a new formula to estimate the smoking economic burden by morbidity. Also introduces an analytic validation from this formula since the mathematic point of view. ${ }^{18}$ Supported in this new formula, the course introduces the use of a new algorithm to determinate the smoking economic burden by morbidity. ${ }^{16}$ However, the most important is the introduction of new epidemiologic conceptions for a better understanding of the smoking economic impact.

2-Postgraduate course: Labor productivity loses attributable to smoking. In this course the student will be capable to describe the labor productivity loses attributable to smoking. Also will estimate the smoking economic burden by labor productivity loses attributable to smoking for each labor productivity loses identified. This course include:

a) The description from the labor productivity relation with the human develop. [19]

b) Description from the smoking incidence over the labor health. [20]

c) Characterization from the labor productivity loses attributable to smoking. [21]

d) Description from the labor productivity lose because of the tobacco consumption during the labor time. [22] e) Description from the labor productivity lose because of the earlier smoker death. [23]

This course raises the labor productivity importance's for the human develop. It defend the idea that the over mortality in active smokers is the difference between life expectative in active smokers and no-active smoker and not in reference to the life expectancy at born.

3-Postgraduate course: Public policies for the smoking economic control. This course is focused in the conception and initial design of public policies for the smoking economic control. The course includes the following:

a) MPOWER Program for the smoking control. Experiences. [24]

b) Characterization from the Cuban domestic tobacco market.

c) Tobacco industry strategy's in Cuba. [25]

d) Fiscal authorities' role in the smoking control. [26]

e) Smoking fiscal space in Cuba. [27]

f) Tributaries policies vs. no tributaries policies for the smoking control. [28]

4-Postgraduate course: The socioeconomic inequity attributable to smoking. This course looks for the characterization of the socioeconomic inequity attributable to smoking. The course includes the following elements:

a) The socioeconomic inequity attributable to smoking. [29]

b) The smoking social costs as socioeconomic inequity form. [30]

c) Instrument to measure the smoking socioeconomic inequity. [31]

d) The smoking socioeconomic inequity in Cuba. [32]

5-Postgraduate Diploma course: the smoking social costs. ${ }^{33}$ this course is large because looks for the analytic and theoric characterization from the smoking social costs. This diploma course includes:

a) Smoking as risk factor.

b) Smoking economic impact over the Public Health.

c) The smoking touchable costs.

d) Critics to the main way estimating the smoking economic impact by morbidity.

e) New formula estimating the smoking economic burden by morbidity.

f) Labor productivity loses attributable to smoking.

g) Socioeconomic inequity attributable to smoking.

h) Economic policy for the smoking control.

This course is 824 hours large and 196 are front of professors. This condition raises the importance of the self-research for students.

In general, the strategy born since the real necessity from the health professionals related to the smoking control in Cuba in subjects from the Health Economy. Nevertheless, authors suggest the diploma courses for professional without sufficient elements from the Health Economy for the smoking economic control. Inside each course a subject is supported by the previous. By this way is possible obtain a logic process in the postgraduate teaching about the smoking economic control.

\section{Conclusions:}

Was designed a postgraduate educational strategic for the smoking economic control in $\mathrm{Cuba}$, agree to real needs from the health professionals related with the smoking control. The strategy includes five postgraduate courses and one of them is a diploma course. This one is the suggested for professional without sufficient elements from the Health Economy for the smoking economic control. 


\section{References:}

1. Fernández Hernández F., Sánchez González E. (2017) Impacto del tabaquismo en el presupuesto sanitario de Cuba 1997-2014. Revista del Hospital Psiquiátrico de La Habana; 14(2)

2. Sánchez González E, Fernández Hernández F. (2017). Caracterización económica general del consumo de cigarrillos en Cuba de 2011 a 2013. Revista del Hospital Psiquiátrico de La Habana: 14(2)

3. Fé F Hernández, Efraín S González. (2020). Personal spends on cigarettes and tobaccos in Cuba from 2013 to 2016. Clinical Reviews and Clinical Trials; 2(2). DOI: 10.31579/CRCT.2020/011

4. Sánchez González E, Fernández Hernández F. (2018). La relación entre la política tributaria y el control del tabaquismo en Cuba. Correo Científico Médico;(2): 238-249

5. Fernández Hernández F., Sánchez González E. (2020). The absolute socioeconomic inequity attributable to smoking; Clinical Reviews and Clinical Trials;2(1): DOI: 10.31579/CRCT.2020/009

6. Fernandez Hernández F., Sánchez Gonzalez E. Economic Inequity Attributable to Smoking Ratio's for the Public Health. Health Economics \& Outcome Research Open Access. 4(161): DOI: $10.4172 / 2471-268 x / 1000161$

7. Fernández Hernández F., Sánchez González E. (2019). La carga económica del tabaquismo. Cuantificación de los costos directos atribuibles al tabaquismo. Editorial Académica Española, Barcelona

8. Sánchez González E., Fernández Hernández F. (2017). Costo de oportunidad por muerte prematura de fumadores activos cubanos en el año 2011. Revista Cubana de Salud y Trabajo; 18(2): 26-31

9. Sánchez González E., Fernández Hernández F. (2020). Characterization of the Socioeconomic Inequity Attributable to Smoking. Journal of Quality in Health care \& Economics; 3(4): DOI: $10.23880 /$ jqhe-16000175

10. ENPA. Actualización del programa integral de desarrollo para producción de tabaco en Cuba. Documento técnico. 2020

11. 11.Programa Nacional de Lucha contra el Tabaquismo. https://temas.sld.cu/tabaquismo/

12. Fernández Hernández F., Sánchez González E. (2020). Contributions since the Health Economy to the smoking control in Cuba. Biomedical Journal of Scientific \& Technician Research; 30(1): DOI: 10.26717/BJSTR..30.004901

13. Sánchez González E, Fernández Hernández F. (2019). A view for the morbidity attributable to smoking since the microeconomic. OAT Trends in Research; 2. DOI: 10.15761/TR.1000151

14. Sánchez González E., Fernández Hernández F. (2020). The smoking economic control across the primary health services. Clinical Reviews and Clinical Trials; 2(2): DOI: 10.31579/CRCT.2020/014

15. Fernández Hernández F, Sánchez González E. (2019). Estimating the economic burden attributable to some risk factor. OAT Journal of Clinical Investigation and Studies; 2 : DOI: $10.15761 /$ JCIS.1000121

16. Fernández Hernández F, Sánchez González E. (2017). Carga epidemiológica vs carga económica del tabaquismo por morbilidad. Revista de Ciencias Médicas de Pinar del Río. 2017; 21(2)210-216

17. Fernández Hernández F., Sánchez González E. (2018). Algorithm to calculate the smoking economical burden in active and passive smokers; 4(6):373-375
18. Fernández Hernández F., Sánchez González E. (2020). Analytic validation of a formula estimating the smoking economic burden. MOJ Public Health; 9(1): 5-7

19. Lightwood J, Glantz SA. (2013). The Effect of the California Tobacco Control Program on Smoking Prevalence, Cigarette Consumption, and Healthcare Costs: 1989-2008. PLoS ONE; 8(2): e47145

20. Fernández Hernández F., Sánchez González E. Smoking incidence over the labor health. Journal of Medical Care Research and Review; 3(8):417-419

21. Sánchez González E., Fernández Hernández F. (2016). La pérdida de productividad laboral atribuible al tabaquismo. Revista Cubana de Salud y Trabajo; 17(2):57-60

22. Fernández Hernández F, Sánchez González E. (2017). Pérdida de productividad por el consumo de cigarrillos en la jornada laboral. Revista Cubana de Salud y Trabajo;18(3):9-12

23. Sánchez González E., Fernández Hernández F. (2018). Costo social por pérdida absoluta de productividad laboral. Revista Cubana de Salud y Trabajo; 19(1): 33-39

24. Arredondo A, Recaman AL, Pinzon C, Azar A. (2018). Financial consequences from smoking-related diseases in middle-income countries: Evidence and lessons from Mexico. Int J Health Plann Mgmt; 33: e454-e463

25. Sánchez González E, Fernández Hernández F. (2020). The fiscal policy and the smoking control in Cuba. Journal of Clinical Research and Reports; 2(4): DOI:10.31579/26901919/025

26. Sánchez González E., Fernández Hernández F. (2017). El rol de las autoridades fiscales en el control del tabaquismo. Revista de Ciencias Médicas de Pinar del Río; 21(3): 362-367

27. Sánchez González E, Fernández Hernández F. (2019). The smoking fiscal space in Cuba. Journal of Clinical and Medical Research; 1(3): 1-5

28. Sánchez González E., Fernández Hernández F. (2020). Brief Appointments about Fiscal Policy for the Smoking Control. Journal of Clinical Research and Reports; 2(5): DOI:10.31579/2690-1919/028

29. Fernández Hernández F., Sánchez González E. (2019). The socioeconomic inequity attributable to smoking. Journal of Medical Practice and Review; 3(6): 559-562

30. Sánchez González E, Fernández Hernández F. (2019). The social inequity across the smoking social costs. Ageing Science \& Mental Health Studies; 3(5): 1-3

31. Sánchez González E., Fernández Hernández F. (2020). Rates to measures the social inequity attributable to smoking. Journal of Clinical Research and Reports; 2(4): DOI:10.31579/26901919/026

32. Fernández Hernández F, Sánchez González E. (2020). The Social and Economic Inequity from Smoking in Cuba. Annals of Medical \& Surgical Case Reports; DOI: AMSCR-100037

33. Fernández Hernández F, Sánchez González E. (2019). Diploma Course: "The Social Smoking Cost in the National Economy", A Necessary and Appliable Tool. HSOA Journal of Community Medicine and Public Health Care. 2019. DOI: 10.24966/CMPH-1978/100052 